\title{
KINERJA KARYAWAN: GAYA KEPEMIMPINAN DAN DISIPLIN KERJA
}

\section{EMPLOYEE PERFORMANCE: LEADERSHIP AND WORK OF DISCIPLINE}

\author{
Sri Langgeng Ratnasari \\ Program Studi Magister Manajemen Program Pascasarjana Universitas Riau Kepulauan \\ sarisucahyo@yahoo.com
}

\begin{abstract}
Abstrak
Gaya kepemimpinan dan disiplin kerja merupakan salah satu dari beberapa faktor yang dapat mempengaruhi kinerja karyawan. Penelitian ini bertujuan untuk menguji dan menganalisis pengaruh gaya kepemimpinan dan disiplin kerja terhadap kinerja pegawai PT. Batam City Investent. Penelitian dilakukan dengan menggunakan regresi linier berganda dengan SPSS untuk menganalisis data. Hasil pengujian hipotesis menunjukkan bahwa gaya kepemimpinan secara parsial berpengaruh signifikan terhadap kinerja karyawan, disiplin kerja berpengaruh secara parsial berpengaruh terhadap kinerja. Gaya kepemimpinan dan disiplin kerja secara simultan berpengaruh signifikan terhadap kinerja pegawai PT. Batam City Investment
\end{abstract}

\section{Kata kunci: Kepemimpinan, Disiplin Kerja, Kinerja Karyawan}

\begin{abstract}
Leadership style and work discipline is one of several factors that might affect the performance of employees. This research aims to examine and analyze the influence of leadership style and work discipline on the performance of employees of PT. Batam City Investent. Research conducted use of multiple linear regression with SPSS to analyze the data. Hypothesis testing results show that leadership style is partially significant effect of employee performance, work discipline partially significant effect on the performance. Leadership style and work discipline simultaneously significant effect on the performance of employees of PT. Batam City Investment.
\end{abstract}

Keywords: The leadership, Work dicipline, Employee performance

\section{PENDAHULUAN}

Pada dasarnya bahwa setiap perusahaan memiliki sumber daya manusia untuk mencapai tujuan. Tanpa adanya sumber daya manusia yang baik maka perusahaan tidak dapat berjalan dengan baik. Sumber daya manusia adalah aset tertinggi yang harus dijaga dengan baik oleh perusahaan. Semua potensi yang dimiliki oleh sumber daya manusia berpengaruh terhadap upaya perusahaan untuk mencapai tujuan. Sumber daya manusia yang dimaksud adalah orang - orang yang memberikan tenaga, pikiran, kreativitas dan usahanya terhadap perusahaan. Harapan dari perusahaan yang akan datang adalah tercapainya tujuan yang maksimal atau mengalami perkembangan yang pesat di dalam lingkup usaha dari perusahaan dan mengiginkan terciptanya kinerja yang baik dalam bidang pekerjaannya. 
Gaya kepemimpinan dapat dikatakan sebagai cara seseorang pemimpin dalam mengarahkan, mendorong dan mengatur seluruh unsur - unsur didalam perusahaan untuk mencapai tujuan yang diinginkan.

Keberhasilan dari suatu perusahaan adalah atas kinerja karyawan sehingga tercapainya target produksi sesuai permintaan dari pelanggan dengan kualitas yang terjamin. Selain faktor gaya kapemimpinan, disiplin kerja juga mempunyai pengaruh yang sangat besar demi kelangsungan jalannya proses pekerjaan dalam suatu perusahaan, disiplin adalah kesadaran dan kesetiaan karyawan untuk melaksanakan dan menyelesaikan setiap pekerjaan dengan selalu mentaati peraturan yang berlaku di dalam perusahaan. Hal yang menjadi masalah dalam kedisiplinan terhadap kinerja karyawan yaitu sering terjadi keterlambatan hadir baik saat masuk maupun setelah selesai istirahat.

Dalam hal ini berarti kurangnya pengawasan dari personalia untuk kontrol dan menindaklanjuti ke departemen terkait.Akibat dari tidak mematuhi peraturan tersebut dapat mengganggu dan merugikan perusahaan dalam menyelesaikan pekerjaan sesuai target yang telah ditetapkan.

Untuk meningkatkan kinerja karyawan kiranya masalah disiplin yang ada di PT. Batam City Investment harus diperhatikan oleh pimpinan. Atas permasalahan tersebut disinilah dituntut peranan pemimpin dalam membimbing dan mengarahkan karyawan, sehingga dapat menciptakan kedisiplinan yang tinggi bagi karyawan, dan kinerja karyawan menjadi maksimal. Dengan demikian dapat mencapai target perusahaan dengan menjaga kualitas yang tetap diutamakan, untuk menghindari komplain dari pelanggan.

\section{Rmusan Masalah}

Berdasarkan latar belakang yang telah dikemukakan, maka rumusan masalah yang akan diteliti dapat dirumuskan sebagai berikut :

1. Apakah gaya kepemimpinan berpengaruh signifikan terhadap kinerja karyawan ?

2. Apakah disiplin kerja berpengaruh signifikan terhadap kinerja karyawan ?

3. Apakah gaya kepemimpinan dan disiplin kerja berpengaruh signifikan secara simultan terhadap kinerja karyawan?

\section{Tujuan Penelitian}

a. Untuk mengetahui pengaruh gaya kepemimpinan secara parsial terhadap kinerja karyawan

b. Untuk mengetahui pengaruh disiplin kerja secara parsial terhadap kinerja karyawan 
c. Untuk mengetahui pengaruh gaya kepemimpinan dan disiplin kerja secara simultan terhadap kinerja karyawan

\section{Manfaat Penelitian}

Dalam penelitian ini diharapkan dapat digunakan untuk :

a. Hasil penelitian ini diharapkan dapat memberikan masukan bagi pengembangan ilmu pengetahuan terutama yang berhubungan dengan sumber daya manusia, yang berkaitan dengan gaya kepemimpinan dan disiplin kerja terhadap kinerja karyawan.

b. Untuk menambah wawasan pengetahuan dan pengalaman dalam bidang penelitian yang berkaitan dengan gaya kepemimpinan dan disiplin kerja terhadap kinerja karyawan.

c. Dapat dijadikan bahan untuk penelitian lebih lanjut bagi pihak - pihak yang akan melakukan penelitian yang sama.

\section{Kerangka Teori}

\section{Gaya Kepemimpinan}

Gaya kepemimpinan adalah suatu usaha yang dapat mempengaruhi satu atau lebih orang lain untuk mengerjakan tujuan dari suatu perusahaan atau organisasi. Menurut Rivai, Hadad dan Ramly (2014) bahwa gaya kepemimpinan adalah sekumpulan ciri yang digunakan pimpinan untuk mempenbgaruhi bawahan agar sasaran organisasi tercapai ata dapat pula dikatakan bahwa gaya kepemimpinan adalah pola perilaku dan strategi yang disukai dan sering diterapkan oleh seorang pemimpin..

Karakteristik seorang pemimpin didasarkan kepada pola dasar seperti : mengarahkan yaitu pemimpin membina dan mengarahkan para bawahan atas tugas - tugas yang diberikan kepada bawahannya, mendukung yaitu pemimpin mendukung kerja bawahan, berpartisipasi yaitu pemimpin bertanya dan menggunakan saran para bawahan. (Rivai, 2006:64)

Kepemimpinan menurut Davis dalam Arifin, 2012)adalah kemampuan mempersuasi orang- orang untuk mencapai tujuan yang tegas dengan gairah (leadership is the ablility to persuade other to seek defined objectives enthusiastically). Sedangkan menurut Terry (dalam Wibisono,2008) kepemimpinan adalah keseluruhan kegiatan(aktifitas untuk mempengaruhi kemauan orang lain untuk mencapai tujuan bersama.

Kepemimpinan menurut Atmosudirdjo (dalam Wibisono) adalah: dianggap sebagai penyebab kegiatan-kegiatan yang dilakukan orang-orang di dalam organisasi. Dirumuskan sebagai kepribadian seseorang yang ingin dicontoh oleh orang lain (bawahannya). Dianggap 
sebagai seni, kesanggupan atau teknik membuat orang-orang untuk mengikuti atau mentaati apa yang dikehendaki. Disebut sebagai pemberi pengaruh terhadap orang-orang tertentu, sehingga mereka bersedia mengubah sikap, pandngan dalam suatu organisasi. Dianggap sebagai suatu bentuk persuasif, seni membina kelompok daengan melakukan motivasi yang tepat agar mereka mau bekerja sama dalam pencapaan tujuan organisasi dipandang sebagai suatu sarana untuk membuat orang-orang mau bekerja sama untuk mencapai tujuan yang telah ditentukan.

Gaya kepemimpinan adalah pola yang menyeluruh adri tindakan seorang pemimpin, baik yang tampak maupun tidak tampak oleh bawahannya. Gaya kepemimpinan menggambarkan kombinasi yang konsisten dari falsafah, ketrampilan dan sikap yang mendasari perilaku seseorang. Gaya kepemimpinan yang menunjukkan, secara langsung maupun tidak langsung tentang keyakinan seorang pimpinan terhadap kemampuan bawahannya. Artinya, gaya kepemimpinan adalah perilaku dan strategi, sebagai hasil kombinasi dari falsafah, ketrampilan, sufat dan sikap yang sering diterapkan seorang pemimpin ketika ia mencoba mempengaruhi kinerja bawahannya.

\section{Teori-teori kepemimpinan}

\section{Teori sifat (thrait theory)}

Teori ini berpandangan bahwa seseorang yang dilahirkan sebagai pemimpin karena memiliki sifat-sifat sebagai pemimpin. Teori ini tidak memungkiri bahwa sifat-sifat kepemimpinan tidak seluruhnya dilahirkan, tetapi juga dicapai dalam suatu proses pendidikan dan pengalaman. Beberapa sifat pemimpin menurut Terry dalam Arifin (2012) adalah sebagi berikut : kekuatan, stabilitas emosi, pengetahuan tentang hubungan kemanusiaan, kejujuran, obyektif, dorongan pribadi, ketrampilan berkomunikasi, kemampuan mengajar, ketrampilan social dan kecakapan teknis atau kecakapan manajerial.

\section{Teori perilaku (behavior theory)}

Kepemimpinan merupakan interaksi pemimpin dengan pengikut, dan dalam interaksi tersebut pengikutlah yang menganalisis dan mempersepsikan apakah menerima atau menolak pengaruh dari pemimpinnya. Melahirkan dua orientasi perilaku pemimpin, yaitu :

1. Berorientasi tugas (task orientation), mengutamakan penyelesaian tugas, dan menampilkan gaya kepemimpinan otokratis.

2. Berorientasi pada orang (people orientation), mengutamakan penciptaan hubunganhubungan manusiawi menampilkan gaya kepemimpinan demokratis atau partisipatif. 


\section{Teori situasional kontigensi (situational kontingensi theory)}

Kepemimpinan berkembang sesuai situasi dan keperluan. Hanya pemimpin yang mengetahui situasi dan keperluan organisasilah yang dapat menjadi pemimpoin yang efektif.(Arifin, 2012)

Versi tambahan(ekstraversi). Pemimpin adalah orang yang enerjik dan bersemangat. Mereka adalah orang yang mampu bersosialisasi, tegas dan jarang diam atau menyerah ( Robbins, 2007).

Kartono (2008) menyatakan sebagai berikut : "Gaya kepemimpinan adalah sifat, kebiasaan, temperamen, watak dan kepribadian yang membedakan seorang pemimpin dalam berinteraksi dengan orang lain".

\section{Disiplin Kerja}

Disiplin kerja adalah suatu alat yang digunakan oleh para manajer untuk berkomunikasi degan karyawan agar mereka bersedia untuk mengubah suatu perilaku serta sebagai suatu upaya untuk meningkatkan kesadaran dan kesediaan seseorang mentaati semua peraturan perusahaan dan norma-norma social yang berlaku (Rivai dan Sagala, 2013)

Tinggi rendahnya tingkat kedisipinan kerja karyawan dapat dilihat dari tingkat absensi dan tingkah laku karyawan dalam mengerjakan tugas - tugasnya. Tingkat absensi yang tinggi menandakan tingkat disiplin kerja karyawan dalam perusahaan rendah, sebaliknya semakin rendah tingkat absensi karyawan berarti disiplin kerja karyawan dalam perusahaan tinggi, dalam hal ini akan sangat membantu perusahaan untuk mencapai sasaran dan tujuannya.

Seorang karyawan dikatakan memiliki disiplin kerja yang tinggi, jika yang bersangkuta konsekwen, konsisten dan taat asas, bertanggung jawab atas tugas yang diamanhkan kepadanya

Terdapat empat perspektif dasar yang menyangkut disiplin kerja, yaitu :

1. Disiplin retributive (retributibe discipline), yaitu berusaha menghukum orang yang berbuat salah

2. Disiplin korektif (corrective discipline), yaitu berusaha membantu karyawann mengoreksi perilakunya yang tidak tepat

3. Perspektif hak-hak individu (individual right perspective), yaitu berusaha melindungi hak-hak individu selama tindakan-tindakan disipliner. 
4. Perspektif utilitarian (utilitarian perspective), yaitu berfokus kepada penggunaan disiplin hanya pada saat konsekuensi-konsekuensi tindakan disiplin melebihi dampak-dampak negatifnya.

\section{Kinerja}

Kinerja merupakan perilaku yang secara langsung berhubungan dengan produksi barang dan penyampaian jasa. Informasi tentang kinerja organisasi atau perusahaan merupakan suatu hal yang sangat penting digunakan untuk mengevaluasi apakah proses kinerja yang dilakukan organisasi atau perusahaan salama ini sudah sejalan dengan tujuan yang diharapkan atau belum. Akan tetapi dalam kenyataannya cukup banyak organisasi atau perusahaan justru kurang atau tidak jarang ada yang mempunyai informasi tentang kinerja dalam organisasinya.

Kinerja sebagai hasil - hasil fungsi pekerjaan atau kegiatan seseorang atau kelompok dalam suatu organisasi yang dipengaruhi oleh berbagai faktor untuk mencapai tujuan organisasi dalam periode waktu tertentu (Wibowo, 2014).

Menurut Rivai dan Basri (2012:187), kinerja merupakan hasil atau tingkat keberhasilan seseorang secara keseluruhan selama periode tertentu dalam melaksanakan tugas dibandingkan dengan berbagai kemungkinan, seperti standar hasil kerja, target atau sasaran, atau kinerja yang telah ditentukan terlebih dahulu dan telah disepakati bersama.

Dalam mencapai tujuan organisasi sangat dipengaruhi perilaku organisasi (organization behavior), yang merupakan pencerminan dari perilaku (behavior) dan sikap (attitude) para pelaku yang terdapat dalam organisasi.

Oleh karena itu keberhasilan dalam mencapai tujuan dari suatu organisasi banyak bergantung kepada perilaku dan sikap individu - individu yang bersinergi diberbagai sumber, seperti sumber daya manusia, sumber daya alam, ilmu pengetahuan dan teknologi.

\section{Pengaruh Antar Variabel}

\section{Pengaruh Gaya Kepemimpinan terhadap Kinerja}

Gaya kepemimpinan yang menunjukkan secara langsung maupun tidak langsung tentang keyakinan seorang pimpinan terhadap kemampuan bawahannya. Artinya, gaya kepemimpinan adalah perilaku dan strategi, sebagai hasil kombinasi dari falsah, ketrampilan, sifat dan sikap yang sering diterapkan seorang pemimpin ketika ia mencoba mempengaruhi kinerja bawahannya. Gaya kepemimpinan harus mampu menyesuaikan dengan perkembangan organisasi, tidak kaku dan harus memiliki fleksibilitas yang tinggi serta 
memiliki arah yang sangat jelas, sehingga akan mampu untuk mengelola seluruh anggota organisasi dengan baik untuk mencapai tujuan organisasi.

\section{Pengaruh Disiplin Kerja terhadap Kinerja}

Disiplin kerja harus dimiliki setiap karyawan dan dapat dibudayakan agar dapat mendukung tujuan organisasi. Disiplin merupakan wujud dari kepatuhan terhadap aturan kerja dan tanggungjawab dari seluruh komponen terhadap perusahaan.

Pelaksanaan disiplin daengan dilandasi adanya kesadaran akan terciptanya kondisi yang harmonis antara keinginan dan kenyataan. Untuk menciptakan kondisi yang harmonis tersebut terlebih dahulu harus diwujudkan keselaraskan antara hak dan kewajiban karyawan. Dengan demikian disiplin kerja berpengaruh terhadap kinerja

\section{Pengaruh Gaya Kepemimpinan dan Disiplin kerja terhadap Kinerja}

Gaya kepemimpinan dan disiplin kerja berpengaruh terhadap kinerja karyawan. Dengan kepemimpinan yang baik dan disiplin yang terjaga dapat memotivasi karyawan untuk dapat menjalankan tugas dan tanggungjawabnya masing-masing, baik secara individu atau kelompok agar tujuan bersama dapat tercapai dengan hasil optimal untuk perusahaan dan karyawan itu sendiri

\section{METODOLOGI}

Penelitian ini dilakukan di PT. Batam City Investment yang berlokasi Orchid Bussines Centre Blok A no 1, Batam. Menggunakan jenis data kuantitatif yang bersumber dari data primer dengan cara menyebarkan kuisioner kepada responden sebagai sumber data utama, yaitu karyawan PT Batam City Investment

Model penelitian ini dapat dilihat pada gambar berikut ini

\section{Hipotesis}

Berdasarkan pada perumusan masalah serta dasar - dasar teori yang telah dipaparkan diatas, maka hipotesis dalam penelitian ini adalah:

1. Ada pengaruh gaya kepemimpinan terhadap kinerja karyawan

2. Ada pengaruh disiplin kerja terhadap kinerja karyawan

3. Ada pengaruh gaya kepemimpinan dan disiplin kerja terhadap kinerja

\section{Populasi dan Sampel}

Populasi dari penelitian ini adalah karyawan PT. Batam City Investment sebanyak 65 orang karyawan yang dijadikan responden. Penelitian ini menggunakan metode sensus yakni menjadikan seluruh karyawan sebagai objek penelitian. Sensus adalah cara pengumpulan data 
dimana seluruh elemen populasi diselidiki satu per satu. Berdasarkan sensus dilapangan, maka sampel dalam penelitian ini diambil keseluruhan yaitu sebanyak 65 orang karyawan.

\section{Definisi Operasional Variabel}

Definisi operasional variabel bertujuan untuk menjelaskan makna variabel yang akan diteliti, Kuncoro (2008:182) definisi operasional adalah unsur penelitian yang memberitahukan bagaimana cara mengukur suatu variabel, dengan kata lain definisi operasional adalah semacam petunjuk pelaksanaan bagaimana mengukur suatu variabel.

a. Gaya kepemimpinan (X1) adalah cara yang digunakan pemimpin didalam wewenang, pengambilan keputusan dan berkomunikasi terhadap karyawan untuk mencapai tujuan perusahaan yang diinginkan.

Indikatornya adalah :

1. Wewenang,

2. Pengambilan Keputusan,

3. Komunikasi, yaitu

b. Disiplin kerja (X2) yaitu suatu aturan yang telah ditetapkan oleh perusahaan kepada karyawan untuk dapat dipatuhi.

Indikatornya adalah :

1. Kehadiran karyawan pada hari kerja.

2. Ketepatan waktu pada saat kehadiran dan pulang kerja

3. Ketaatan karyawan terhadap peraturan yang telah ditetapkan oleh perusahaan.

c. Kinerja karyawan (Y) adalah hasil kerja secara kualitas dan kuantitas yang dicapai oleh karyawan dalam melaksanakan tugasnya yang sesuai dengan tanggung jawab yang telah diberikan oleh perusahaan.

Indikatornya adalah :

1. Kuantitas kerja

2. Kualitas Kerja,

3. Ketepatan waktu,

4. Efektivitas,

5. Kemandirian,

\section{Teknik Pengumpulan Data}

Data yang digunakan dalam penelitian ini ada dua jenis data yaitu data primer dan data sekunder. Data primer di dapat langsung dari karyawan PT. Batam City Investment dengan 
menyebarkan kuisioner. Sedangkan data sekunder didapat dari buku-buku yang berhubungan dengan penelitian ini.

\section{Teknik Analisis Data}

Teknik analisis data menggunakan analisis kuantitatif dengan analisis regresi linier dengan bantuan software SPSS. Persamaan regresi linier, adalah:

$$
\mathrm{Y}=\mathbf{a}+\mathbf{b 1} . \mathrm{X} 1+\mathbf{b 2 . X 2}+\mathrm{e}
$$

Dimana:

$\mathrm{Y}=$ Variabel dependen (Kinerja Karyawan)

$\mathrm{a}=$ Konstanta

b1, b2 = Koefisien garis regresi

$\mathrm{X} 1, \mathrm{X} 2=$ Variabel independen (Gaya kepemimpinan, Disiplin kerja)

$\mathrm{e}=$ Error / variabel pengganggu

\section{Hasil Penelitian dan Pembahasan}

Berdasarkan hasil penelitian yang telah dilakukan terhadap 65 responden melalui penyebaran kuisioner, diperoleh dari uji validitas bahwa instrumen variabel dinyatakan valid dan reliable, sehingga layak untuk dijadikan data penelitian

\section{Analisis Regresi linier Berganda}

Analisis regresi linier berganda digunakan untuk mengukur pengaruh antara gaya kepemimpinan (X1) dan disiplin kerja (X2) terhadap kinerja karyawan (Y). dengan menggunakan bantuan program SPSS, maka diperoleh nilai-nilai untuk regresi linier berganda sebagai berikut :

\begin{tabular}{|c|c|c|c|c|c|c|c|c|c|}
\hline \multirow[b]{3}{*}{ Model } & \multicolumn{9}{|c|}{$\begin{array}{c}\text { Tabel } 1 \\
\text { Hasil Uji Nilai Regresi Berganda } \\
\text { Coefficients }^{\text {au }}\end{array}$} \\
\hline & \multicolumn{2}{|c|}{$\begin{array}{l}\text { Unstandardized } \\
\text { Coefficients }\end{array}$} & \multicolumn{3}{|l|}{$\begin{array}{l}\text { Standardized } \\
\text { Coefficients }\end{array}$} & \multicolumn{4}{|c|}{$\begin{array}{l}95 \% \quad \text { Confidence Collinearity } \\
\text { Interval for B } \quad \text { Statistics }\end{array}$} \\
\hline & $\mathrm{B}$ & Std. Error & Beta & $\mathrm{T}$ & Sig. & $\begin{array}{l}\text { Lower } \\
\text { Bound }\end{array}$ & $\begin{array}{l}\text { Upper } \\
\text { Bound }\end{array}$ & Tolerance & VIF \\
\hline 1 (Constant) & 34.326 & 9.242 & & 3.714 & .000 & 15.852 & 52.800 & & \\
\hline $\begin{array}{l}\text { Gaya } \\
\text { Kepemimpi } \\
\text { nan }\end{array}$ & .366 & .147 & .268 & 2.482 & .016 & .071 & .661 & .709 & 1.410 \\
\hline $\begin{array}{l}\text { Disiplin } \\
\text { Kerja }\end{array}$ & .672 & .141 & .515 & 4.771 & .000 & .391 & .954 & .709 & 1.410 \\
\hline
\end{tabular}

a. Dependent Variable: Kinerja

Karyawan

Sumber : Data primer diolah, 2017 
Berdasarkan tabel 1 diatas hasil persamaan regresi dapat dijelaskan sebagai berikut: $\mathrm{Y}=34.326+0.366 \mathrm{X} 1+0.672 \mathrm{X} 2$

Dari persamaan diatas dapat dijelaskan bahwa :

a. Nilai konstanta a sebesar 34.326 artinya jika gaya kepemimpinan dan disiplin kerja tidak ada maka kinerja karyawan sebesar 34.326.

b. Nilai konstanta b1 sebesar 0.366. Hal ini menjelaskan bahwa gaya kepemimpinan berpengaruh positif terhadap kinerja karyawan. Jika gaya kepemimpinan semakin baik dengan asumsi nilai variabel yang lain tetap, maka kinerja karyawan akan mengalami peningkatan 0.366. Jadi semakin baik gaya kepemimpinan, maka semakin meningkat kinerja karyawan.

c. Nilai koefisien b2 sebesar 0.672. Hal ini menjelaskan bahwa disiplin kerja berpengaruh positif terhadap kinerja karyawan. Jika disiplin kerja semakin tinggi dengan asumsi nilai variabel yang lain tetap maka kinerja karyawan akan mengalami peningkatan sebesar 0.672. Jadi semakin tinggi disiplin kerja maka semakin meningkat kinerja karyawan.

Uji t

Selanjutnya untuk mengetahui apakah secara parsial variabel bebas gaya kepemimpinan (X1) dan disiplin kerja (X2) mempunyai pengaruh yang signifikan terhadap kinerja karyawan dapat dilihat pada tabel berikut :

Tabel 2 Uji t (Parsial)

Coefficients $^{\mathrm{a}}$

\begin{tabular}{ccccc}
\hline \multicolumn{2}{c}{$\begin{array}{c}\text { Unstandardized } \\
\text { Coefficients }\end{array}$} & $\begin{array}{c}\text { Standardized } \\
\text { Coefficients } \\
\text { Beta }\end{array}$ & T & Sig. \\
\hline 34.326 & 9.242 & & 3.714 & .000 \\
.366 & .147 & .268 & 2.482 & .016 \\
.672 & .141 & .515 & 4.771 & .000 \\
\hline
\end{tabular}

a. Dependent Variable: Kinerja Karyawan

\section{Uji Hipotesis 1 (H1)}

Dari Tabel 2 terlihat bahwa hasil pengujian hipotesis gaya kepemimpinan menunjukkan nilai t hitung sebesar 2.482 dengan taraf signifikan 0.016. Taraf signifikansi sebesar 0.016 tersebut lebih kecil dari 0.05. Berarti bahwa hipotesis dalam penelitian ini 
bahwa gaya kepemimpinan berpengaruh signifikan terhadap kinerja karyawan PT. Batam City Investment.

Dengan demikian Ho diterima dan Ha ditolak, kesimpulannya bahwa hipotesis H1 "Gaya Kepemimpinan” berpengaruh signifikan terhadap kinerja karyawan” diterima".

\section{Uji Hipotesis 2 (H2)}

Dari Tabel 2 terlihat bahwa hasil pengujian hipotesis disiplin kerja menunjukkan nilai t hitung sebesar 4.771 dengan taraf signifikan 0.000. Taraf signifikansi sebesar 0.000 tersebut lebih kecil dari 0.05 . Berarti bahwa hipotesis dalam penelitian ini bahwa disiplin kerja berpengaruh signifikan terhadap kinerja karyawan PT. Batam City Investment.

Dengan demikian Ha diterima dan Ho ditolak, kesimpulannya bahwa hipotesis H2 "Disiplin Kerja" berpengaruh signifikan terhadap kinerja karyawan" diterima".

\section{Uji F (Simultan)}

Tabel 3

Hasil Analisis Regresi Secara Simultan ANOVA $^{\circ}$

\begin{tabular}{lllllll}
\hline Model & & Sum of Squares & Df & Mean Square & F & Sig. \\
\hline 1 & Regression & 2030.988 & 2 & 1015.494 & 29.393 & $.000^{\mathrm{a}}$ \\
& Residual & 2141.996 & 62 & 34.548 & & \\
& Total & 4172.985 & 64 & & & \\
\hline
\end{tabular}

a. Predictors: (Constant), Disiplin Kerja, Gaya Kepemimpinan

b. Dependent Variable: Kinerja Karyawan

Berdasarkan hasil perhitungan pada Tabel 3 diketahui hasil menunjukkan nilai $\mathrm{F}$ hitung sebesar 29,393 dengan signifikan 0,000. Nilai signifkan tersebut lebih kecil dari 0,05. Hal ini menyatakan bahwa secara simultan variabel gaya kepemimpinan dan disiplin kerja mempunyai pengaruh signifikan terhadap kinerja karyawan.

\section{Koefisien Determinasi (R2)}

Untuk mengetahui hubungan antara variabel gaya kepemimpinan dan disiplin kerja terhadap kinerja karyawan dapat dilihat dari nilai $\mathrm{R}$ tabel sebagai berikut:

Tabel 4

\section{Hasil Uji Nilai Koefisien Determinan} Model Summary ${ }^{\mathrm{D}}$

\begin{tabular}{|c|c|c|c|c|c|c|c|c|c|c|}
\hline Model & $\mathrm{R}$ & $\begin{array}{l}\mathrm{R} \\
\text { Square }\end{array}$ & $\begin{array}{l}\text { Adjusted } \\
\text { R Square }\end{array}$ & $\begin{array}{l}\text { Std. Error } \\
\text { of the } \\
\text { Estimate }\end{array}$ & $\begin{array}{l}\text { Change Stat } \\
\mathrm{R} \text { Square } \\
\text { Change }\end{array}$ & $\begin{array}{l}\text { tistics } \\
\text { F } \\
\text { Change }\end{array}$ & df1 & $\mathrm{df2}$ & $\begin{array}{l}\text { Sig. } \\
\text { Change }\end{array}$ & $\begin{array}{l}\text { F Durbin- } \\
\text { Watson }\end{array}$ \\
\hline 1 & $.698^{\mathrm{a}}$ & .487 & .470 & 5.87778 & .487 & 29.393 & 2 & 62 & .000 & 2.145 \\
\hline
\end{tabular}


Model Summary

\begin{tabular}{|c|c|c|c|c|c|c|c|c|c|}
\hline Model & $\mathrm{R}$ & $\begin{array}{l}\mathrm{R} \\
\text { Square }\end{array}$ & $\begin{array}{l}\text { Adjusted } \\
\text { R Square }\end{array}$ & $\begin{array}{l}\text { Std. Error } \\
\text { of the } \\
\text { Estimate }\end{array}$ & $\begin{array}{l}\text { Change Stat } \\
\text { R Square } \\
\text { Change }\end{array}$ & $\begin{array}{l}\text { tistics } \\
\text { F } \\
\text { Change df1 }\end{array}$ & $\mathrm{df2}$ & $\begin{array}{l}\text { Sig. } \\
\text { Change }\end{array}$ & $\begin{array}{l}\text { F Durbin- } \\
\text { Watson }\end{array}$ \\
\hline 1 & $.698^{\mathrm{a}}$ & .487 & .470 & 5.87778 & .487 & 29.3932 & 62 & .000 & 2.145 \\
\hline
\end{tabular}

Berdasarkan Tabel 4 diperoleh nilai koefisien korelasi (R) sebesar 0.698 dengan nilai interprestasi koefisien korelasi 0,600 - 0,799 berarti ada pengaruh yang kuat. Dalam hal ini menjelaskan ada hubungan antara gaya kepemimpinan dan disiplin kerja terhadap kinerja karyawan. Sedangkan nilai koefisien determinasi $R^{2}$ (R Square) diperoleh nilai sebesar 0,487 yang artinya gaya kepemimpinan dan disiplin kerja memiliki pengaruh terhadap kinerja karyawan sebesar $48,70 \%$, sedangkan sisanya $42,30 \%$ dipengaruhi oleh variabel lain yang tidak dimasukkan dalam variabel penelitian ini.

\section{PEMBAHASAN}

Berdasarkan hasil perhitungan dan analisis diatas, diperoleh persamaan regresi linier berganda sebagai berikut :

$$
\mathrm{Y}=34.326+0.366 \mathrm{X} 1+0.672 \mathrm{X} 2
$$

Hasil persamaan regresi linier berganda ini menunjukkan gaya kepemimpinan (X1) dan disiplin kerja (X2) bernilai positif terhadap kinerja. Artinya apabila variabel gaya kepemimpinan dan disiplin kerja ditingkatkan, makan akan meningkat pula kinerja karyawan

Variabel gaya kepemimpinan dan disiplin kerja secara bersama - sama mempunyai pengaruh yang signifikan terhadap kinerja. Hal ini didukung oleh hasil nilai F sebesar 29,393 dengan signifikan yang diperoleh 0,000 lebih kecil 0,05. Artinya apabila gaya kepemimpinan dan disiplin kerja dilakukan secara bersama - sama akan mempengaruhi kinerja karyawan.

\section{Hasil Analisis Gaya Kepemimpina}

Berdasarkan pengujian hipotesis pertama (H1) telah membuktikan terdapat pengaruh gaya kepemimpinan terhadap kinerja karyawan. Adapun hasil perhitungan yang telah dilakukan diperoleh nilai t sebesar 2,482 dengan signifikansi sebesar 0,016. Nilai signifikan tersebut lebih kecil dari 0,05.

Dalam hal ini berarti gaya kepemimpinan dengan wewenang, pengambilan keputusan dan komunikasi mendukung karyawan dalam bekerja dan mampu memberikan peningkatan kinerja dalam mencapai tujuan perusahaan. Sehingga gaya kepemimpinan mempunyai 
peranan penting dalam memberikan petunjuk kepada karyawan dalam menyelesaikan tugas tugasnya.

\section{Hasil Analisis Disiplin Kerja}

Berdasarkan pengujian hipotesis kedua $(\mathrm{H} 2)$ telah membuktikan terdapat pengaruh disiplin kerja terhadap kinerja karyawan. Adapun hasil perhitungan yang telah dilakukan diperoleh nilai t sebesar 4,771 dengan signifikansi sebesar 0,000. Nilai signifikan tersebut lebih kecil dari 0,05 .

Dalam hal ini berarti dengan adanya kedisiplinan yang tinggi seperti kehadiran, tepat waktu masuk dan pulang kerja dan ketaatan terhadap peraturan serta melakukan tugas dan kewajiban telah mampu memberi peningkatan terhadap kinerja karyawan. Dengan kedisiplinan yang tinggi yang dimiliki karyawan yang mampu memberikan peningkatan kinerja dalam pencapaian target perusahaan juga akan semakin membaik.

Berdasarkan hasil tersebut diatas dapat disimpulkan dari kedua variabel tersebut hanya variabel disiplin kerja yang memberikan pengaruh dominan terhadap kinerja karyawan. Hal ini didukung dengan nilai t hitung terbesar dibandingkan dengaan variabel lainnya yaitu 4,771 dengan nilai signifikan 0,000 .

\section{KESIMPULAN DAN SARAN}

\section{Kesimpulan}

Berdasarkan hasil analisa data diatas, dapat diambil kesimpulan sebagai berikut:

1. Gaya Kepemimpinan mempunyai pengaruh signifikan terhadap kinerja karyawan. Dalam hal ini menunjukkan bahwa gaya kepemimpinan dengan wewenang, pengambilan keputusan dan komunikasi dapat meningkatkan kinerja karyawan

2. Disiplin kerja mempunyai pengaruh signifikan terhadap kinerja karyawan. Dalam hal ini menunjukkan bahwa kehadiran, ketepatan waktu masuk dan pulang kerja dan ketaatan pada peraturan dapat meningkatkan kinerja karywan

3. Gaya Kepemimpinan dan disiplin kerja mempunyai pengaruh yang signifikan terhadap kinerja karyawan. Bahwa dengan pemimpin yang komunikatif dan disiplin dari seluruh komponen dapat meningkatkan kinerja karyawan

\section{Saran}

Berdasarkan hasil penelitian dan pembahasan diatas, maka dapat diajukan saran - saran sebagai berikut : 
1. Untuk meningkatkan kinerja dan produktivitas karyawan, maka manajemen PT. Batam City Investment harus mempertahankan dan meningkatkan pola komunikasi, pembagian tugas wewenang yang sudah berjalan dengan baik.

2. Dari hasil penelitian mengenai disiplin kerja dari karyawan PT. Batam City Investment perlu adanya perbaikan. Dengan kedisiplinan kerja yang tinggi dapat meningkatkan kinerja karyawan, sehingga kerjasama yang dibangun secara bersama - sama dapat meningkat dan produktif.

3. Hasil penelitian mengenai kinerja karyawan di PT. Batam City Investment harus melakukan pelatihan untuk meningkatkan kemampuan dalam melakukan pekerjaan dan mengembangkan potensi - potensi dalam masing - masing karyawan agar memiliki inisiatif yang baik dalam bekerja.

\section{REFERENSI}

Arifin, Syamsul. 2012. Leadership. Ilmu dan Seni Kepemimpinan. Jakarta. PT Mitra Wacana Media.

Ashrahenny dan Ratnasari, Sri Langgeng. 2016. Pengaruh Gaya Kepemimpinan Dan Komunikasi Terhadap Kinerja Karyawan PT. Hi-Test (Laboratory Of Mechanical Testing). Zona Manajemen ISSN 2087-6998. Fakultas Ekonomi Universitas Batam. Volume 8, Nomor 3, Desember 2016. Hal. 1-10.

Darmayanti dan Ratnasari, Sri Langgeng. 2016. Pengaruh Gaya Kepemimpinan Dan Fasilitas

Kerja Terhadap Kinerja Pegawai Pada Kantor Camat Batam Kota. Zona Manajemen ISSN 2087-6998. Fakultas Ekonomi Universitas Batam. Volume 8, Nomor 1, April 2016. Hal. 11-18

Ghozali, Imam. 2014. Aplikasi Analisis Multivariate dengan Program SPSS. Semarang. BPUniversitas Diponegoro.

Istijanto. 2006. Riset sumber Daya Manusia Cara Praktis Mendeteksi Dimensi-Dimensi Kerja Karyawan. Jakarta. Bumi Aksara.

Kartono, Kartini. 2008. Pemimpin dan Kepemimpinan Abnormal. Jakarta. Rajagrafindo Persada

Lilo, Christianto dan Ratnasari, Sri Langgeng. 2015. Pengaruh Gaya Kepemimpinan Dan Kompensasi Terhadap Kinerja Karyawan Pada PT. Supreme Nusapermai Development. Zona Manajerial. ISSN 2087-7331. Volume 7 Nomor 2, Agustus 2015. Hal. 50-69. Fakultas Ekonomi Universitas Batam 
Murwanto, Didik dan Ratnasari, Sri Langgeng. 2016. Pengaruh Kompensasi dan Gaya Kepemimpinan Terhadap Motivasi Kerja Karyawan PT. Fast Precision Manufacturing Indonesia. Zona Manajerial. ISSN 2087-7331. Volume 8 Nomor 1, April 2016. Hal. 1-12. Fakultas Ekonomi Universitas Batam

Mangkunegara, A.A. 2007. Evaluasi Kinerja SDM. Bandung. PT Refika Aditama.

Ratnasari, Sri Langgeng, Budiman Christiananta, dan Anis Eliyana. 202. Pengaruh Komitmen Organisasional dan Budaya Organisasi Terhadap Kepuasan serta Prestasi Kerja Dosen Tetap Yayasan Perguruan Tinggi Swasta di Provinsi Kepulauan Riau. Jurnal Akuntansi dan Manajemen (JAM) ISSN: 0853-1269, STIE YKPN Yogyakarta, Vol. 23, No.1, April 2012, TERAKREDITASI SK DIRJEN DIKTI NO.:64a/DIKTI/Kep./2010 Tanggal 1 Nopember 2010. Hal 51-60

Robbins, P. 2007. Perilaku Organisasi. Jakarta. Salemba Empat.

Rivai, Veithzal dan Basri. 2012. Performance Appraisal: Sistem yang tepat untuk menilai Kinerja Karyawan dan meningkatkan Daya Saing Perusahaan. Jakarta. Rajagrafindo Persada.

Rivai, Veithzal dan Sagala, Ella J.. 2013. Manajemen Sumber Daya Manusia untuk Perusahaan dari Teori ke Praktik. Jakarta. Rajagrafindo Persada.

Rivai, Hadad dan Ramly. 2014. Kepemimpinan dan Perilaku Organisasi. Edisi Ke empat. Jakarta. Rajagrafindo Persada.

Wibowo. 2014. Manajemen Kinerja. Jakarta. Rajagrafindo Persada 